Primljen / Received: 17.5.2016. Ispravljen / Corrected: 24.9.2016.

Prihvaćen / Accepted: 7.10.2016.

Dostupno online / Available online: 10.12.2016.

\title{
Controlled seismic behaviour of masonry-infilled steel frames
}

\section{Authors:}

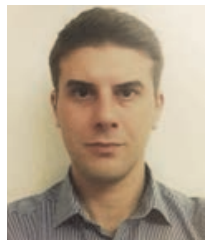

Assist.Prof. Ivan Radić, PhD. CE University of J.J. Strossmayer in Osijek Faculty of Civil Engineering Osijek radic@gfos.hr

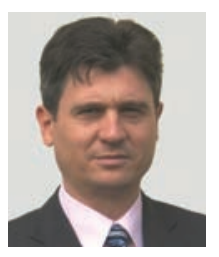

Prof. Damir Markulak, PhD. CE University of J.J. Strossmayer in Osijek Faculty of Civil Engineering Osijek markulak@gfos.hr

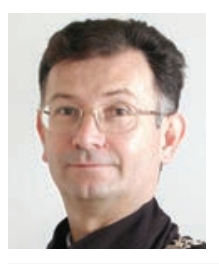

Prof.dr.sc. Vladimir Sigmund
Original scientific paper

\author{
Ivan Radić, Damir Markulak, Vladimir Sigmund
}

\section{Controlled seismic behaviour of masonry-infilled steel frames}

Whether used as a curtain/partition wall or a bearing part of the structure, masonry infill significantly affects structural behaviour of the primary structure. Two different types of masonry units ('strong' and 'weak'), often used in Croatia as infill of steel frames, are initially considered in the paper. Based on experimental results obtained by testing behaviour of these two types of masonry units, a third type of infill is proposed, which is a specific combination of the initial two types, and enables realisation of controlled behaviour of masonry-infilled steel frames.

Ključne riječi:
masonry infill, steel frames, frame to infill interaction, controlled seismic behaviour

Izvorni znanstveni rad

Ivan Radić, Damir Markulak, Vladimir Sigmund

\section{Kontrolirano seizmičko ponašanje čeličnih okvira sa zidanom ispunom}

Bilo da se radi o pregradnim ili nosivim zidovima, zidana ispuna značajno utječe na ponašanje primarne konstrukcije. U ovom se radu najprije razmatraju dvije različite vrste zidnih blokova (tzv. jaki i slabi) često korištenih u Hrvatskoj kao ispune čeličnih okvira. Na osnovu eksperimentalnih rezultata dobivenih ispitivanjem ponašanja tih dviju vrsta blokova predložena je treća vrsta ispune koja predstavlja specifičnu kombinaciju prethodnih dviju, kao mogućnost ostvarivanja kontroliranog ponašanja čeličnih okvira sa zidanom ispunom.

Ključne riječi:

zidana ispuna, čelični okviri, interakcija okvira i ispune, kontrolirano seizmičko ponašanje

Wissenschaftlicher Originalbeitrag

\section{Ivan Radić, Damir Markulak, Vladimir Sigmund}

\section{Kontrolliertes seismisches Verhalten von Stahlrahmen mit Mauerwerksausfachungen}

Unabhängig davon, ob es sich um Trennwände oder tragende Wände handelt, beeinflusst ausfachendes Mauerwerk das Verhalten des primären Tragwerks bedeutend. In dieser Arbeit werden zunächst zwei verschiedene Typen von Mauerwerksblöcken betrachtet (s. g. starke und schwache), die in Kroatien als Ausfachung verwendet werden. Basierend auf experimentellen Resultaten aus Versuchen an diesen Blöcken, wurde als ihre spezifische Kombination ein dritter Mauerwerkstyp vorgeschlagen, um ein kontrolliertes Verhalten von Stahlrahmen mit Mauerwerksausfachungen vorzuschlagen.

Ključne riječi:

Mauerwerksausfachung, Stahlrahmen, Interaktion von Rahmen und Ausfachung, Kontrolliertes seismisches Verhalten 


\section{Introduction}

Masonry products made of clay, lightweight concrete or similar types of aggregate are among the materials most commonly used in building construction due to their availability, acceptable cost, generally good physical properties, and easy production and installation. These products can be used as load-bearing elements or as an infill to/in main structural elements, such as steel or concrete frames. Although the fact that the presence of infill affects behaviour of the main structural system is well known, there are still no specific methods or detailed design rules for the analysis of these interactive, combined structures called masonry-infilled frames. The problem is that the effects of infill can be either beneficial (for example increased stiffness and bearing capacity of the structure) or detrimental (prying actions in steel connections caused by big diagonal compression forces in the infill, short column effect, etc.), which depends on many various parameters related to structural configuration, geometric properties of masonry panels, material properties, etc. [1]. Furthermore, the majority of material characteristics of infill strongly depend on constituent parts and on construction procedure, so that structural behaviour of infilled frames is strongly nonlinear. Therefore, a combination of experimental and analytical methods is still usually required for proper design and structural modelling of masonry-infilled frames.

Close attention should be paid to the interface between the frame and infill panel. Generally, three different situations are possible and recognized by current codes [2]: infill panel is positively connected to steel frame elements, infill panel is structurally disconnected from steel frame elements, and infill panel is in contact with steel frame elements but is not positively connected to them. This third case is actually the most common situation in which masonry infill is used, and so structural configuration is considered in this paper.

In the current engineering practice, there are two basic approaches for improving an overall behaviour of masonryinfilled frames [1]:

a) Strengthening masonry infill by various methods in order to improve the resistance and monolithic behaviour of the frame and infill,

b) Limiting frame-infill interaction by certain provisions or devices, in order to reduce infill damage and its detrimental effects to the frame.

It should be noted that these approaches are completely opposite, which additionally substantiates the lack of full understanding of structural behaviour of the masonry-infilled frames.

The deficiency of the first approach is that additional stiffness of the masonry panel further decreases natural period of the infilled frame which, in turn, results in higher seismic load imposed on the structure. Furthermore, structural behaviour is thus even more affected by the masonry while its main properties remain the same - it is generally fragile, prone to sudden cracking, shattering and spalling, which can cause lifethreatening situations. Besides, this is the reason why frames infilled with masonry are generally regarded as "earthquake risk" structural systems. The main issue of the second solution is the necessity to introduce additional devices that enable complete separation of the frame from infill. That often significantly complicates construction process and decreases practical applicability of a solution.

The option presented in this paper involves an engineer"s intuitive approach to encompass complex behaviour of infilled frames, which is directed towards a "compromise" solution. That solution partly includes favourable effects of both mentioned approaches (strengthening the masonry infill and limiting the frame-infill interaction): an increased stiffness, strength and dissipation capacity of the infilled frame system and, at the same time, preservation of ductile behaviour of the bare steel frame.

\section{Problem formulation}

The idea of controlling key parameters influencing structural behaviour of masonry-infilled frames (or any other types of structures) is not of recent origin. Many methods have been proposed in this respect, and some of them are presented in [3-5]. As mentioned earlier, most of these methods imply the use of appropriate devices that have to be both specifically manufactured and properly installed in order to separate masonry panel from the frame, and achieve desired structural response. That usually means providing a certain gap between the masonry panel and frame elements, which consequently requires proper care from the aspect of thermal, sound, and fire protection of the analysed wall/partition. Although the mentioned facts are far from unsolvable and do not automatically exclude the use of the above mentioned controlling methods, the truth is that they inevitably lead to a more complex construction process. Consequently, the question is often raised about whether there is a real need for using controlling methods, or if another more common solution can be found (for instance, replacing masonry infill with some other material, etc.).

From that point of view, it seems logical to keep looking for solutions that ensure the desired mode of behaviour while at the same time not being overly complex with regard to provisions that have to be respected, at least for this type of structures. Otherwise, the biggest advantages of masonry (as pointed out in the very first sentence of this paper) could be seriously compromised.

One of the possibilities to achieve this goal is considered in this paper. It implies combining two different kinds of masonry infill that are specifically arranged within the steel frame. These two kinds of masonry infill exhibit different mechanical properties and consist of perforated clay units as the "strong" masonry infill, and lightweight autoclaved aerated concrete (AAC) units as the "weak" type of infill. The "weaker" material 
is placed adjacent to the frame while the "stronger" one fills the rest of the panel, thus creating a sort of composite infill. The strength of the "weaker" material should provide for compactness of the infill panel and its resistance up to a certain load level, optimally the one that corresponds to structural performance needed for the serviceability limit state or lower seismic excitation. When the lateral load exceeds that predetermined load level, a partial separation along the frame-infill interface should be enabled by gradual cracking and crushing of the "weak" masonry units placed next to steel frame elements. A monolithic behaviour of the infilled frame could thus be ensured for the predetermined load level (i.e. interstorey drift level), whereas the steel frame takes over and provides for structural stability at higher load levels, thus avoiding possible negative influence of infill. This research is aimed at proving correctness of that idea.

\section{Experimental texting}

In order to adjust structural behaviour of masonry composite infill it was first necessary to investigate relevant characteristics of particular types of masonry infill and all other constituting parts of the infilled frame (steel frame material, mortar and masonry wallets).

The first tests were carried out on masonry units: perforated clay blocks (used for "strong" masonry infill, C-ispecimens), AAC blocks ("weak" infill, A-ispecimens) and bored AAC blocks (used together with perforated clay blocks for combined infill, CA- $i$ specimens) (Figure 1).

The testing was conducted according to relevant European codes. Compressive strength results obtained for masonry units are presented in Table 1 . The second batch of tests
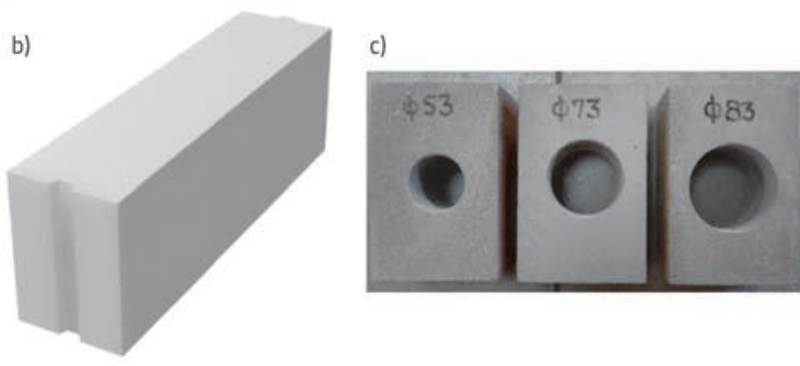

Table 1. Compressive strength of masonry units

\begin{tabular}{|c|c|c|c|c|c|c|c|c|c|}
\hline \multirow{3}{*}{ Sample } & \multicolumn{2}{|c|}{ Clay blocks } & \multirow{3}{*}{$\begin{array}{c}\text { AAC blocks } \\
\mathbf{f}_{\mathrm{m}, \mathrm{h}} \\
{\left[\mathrm{N} / \mathrm{mm}^{2}\right]}\end{array}$} & \multicolumn{6}{|c|}{ AAC drilled blocks } \\
\hline & \multirow{2}{*}{$\begin{array}{c}\mathbf{f}_{\mathrm{m}, \mathrm{v}} \\
{\left[\mathrm{N} / \mathrm{mm}^{2}\right]}\end{array}$} & \multirow{2}{*}{$\begin{array}{c}\mathbf{f}_{\mathrm{m}, \mathbf{h}} \\
{\left[\mathrm{N} / \mathrm{mm}^{2}\right]}\end{array}$} & & \multicolumn{3}{|c|}{$\begin{array}{c}\mathbf{f}_{\mathrm{m}, \mathrm{v}} \\
{\left[\mathrm{N} / \mathrm{mm}^{2}\right]}\end{array}$} & \multicolumn{3}{|c|}{$\begin{array}{c}\mathbf{f}_{\mathrm{m}, \mathrm{h}} \\
{\left[\mathrm{N} / \mathrm{mm}^{2}\right]}\end{array}$} \\
\hline & & & & $\varnothing 54 \mathrm{~mm}$ & $\varnothing 74 \mathrm{~mm}$ & $\varnothing 84 \mathrm{~mm}$ & $\varnothing 54 \mathrm{~mm}$ & $\varnothing 74 \mathrm{~mm}$ & $\emptyset 84 \mathrm{~mm}$ \\
\hline 1 & 13,3 & 2,3 & 2,2 & 2,0 & 2,1 & 1,8 & 0,8 & 0,5 & 0,3 \\
\hline 2 & 13,3 & 2,0 & 2,3 & 2,1 & 2,1 & 1,7 & 1,2 & 0,5 & 0,3 \\
\hline 3 & 13,3 & 2,1 & 2,1 & 2,3 & 2,2 & 1,6 & 0,7 & 0,3 & 0,4 \\
\hline 4 & 12,6 & 2,0 & 2,1 & 1,9 & 1,9 & 1,5 & 0,8 & 0,5 & 0,3 \\
\hline 5 & 13,0 & 2,0 & 1,9 & 2,3 & 2,0 & 1,4 & 0,8 & 0,3 & 0,3 \\
\hline 6 & 12,8 & 1,9 & 2,2 & 2,1 & 1,9 & 1,6 & 1,0 & 0,5 & 0,3 \\
\hline
\end{tabular}

included determination of mechanical characteristics of masonry wallets (Figure 2), steel from the frame, and mortar to be used in the masonry. The average yield strength and tensile strength of steel amounted to $337 \mathrm{~N} / \mathrm{mm}^{2}$ and $483 \mathrm{~N} / \mathrm{mm}^{2}$, respectively. The average compressive strength of mortar used in the strong infill masonry (C-i specimens) and combined infill (CA-ispecimens) was $5,0 \mathrm{~N} / \mathrm{mm}^{2}$. The adhesive mortar with an average compressive strength of $9,1 \mathrm{~N} / \mathrm{mm}^{2}$ was used in weak masonry infill made of AAC blocks (A-ispecimens).
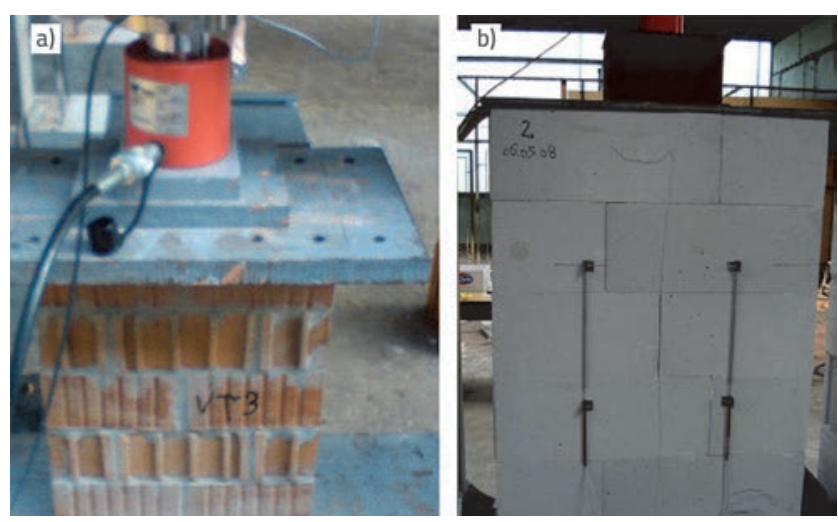

Figure 2. Vertical compression test of masonry wallets: a) C - wallet; b) AAC - wallet 
The average vertical characteristic compressive strength of masonry wallets made of perforated clay blocks (C-wallet) and AAC blocks (AAC-wallet) amounted to 1,6 and 0,9 N/ $\mathrm{mm}^{2}$, respectively. More data related to investigation of these material characteristics can be found in [1].

Then, nine one-bay, one-storey planar steel frames, divided into three series according to the type of masonry infill, and one bare steel frame, were built and tested at the Faculty of Civil Engineering, University of Osijek [1]. All steel frames were of equal size, with rigid frame joints and dimensions as shown in Figure 3.

Conclusions drawn from the observed behaviour of $\mathrm{C}-i$ and $\mathrm{A}-i$ series of specimens were used for the design of the combined composite infill. In order to simulate the desired "twomode" structural behaviour, the goal was set in experimental investigation of the composite infill to keep the central part of the infill generally undamaged. Due to lack of design methods accurate enough to predict the crashing load in the composite infill panel, the AAC blocks were additionally weakened by drilling vertical holes with three different diameters (d) for each specimen in the series (e.g. CA-1: $d=53 \mathrm{~mm}, C A-2: d=73 \mathrm{~mm}$ and CA-3: $d=83 \mathrm{~mm}$ ).

Two hydraulic actuators with the load capacity of $350 \mathrm{kN}$ and stroke limit of $\pm 150 \mathrm{~mm}$ were fixed onto the steel reaction frame in order to apply cyclic in-plane lateral load to specimens. The actuators were positioned to the left and right of the steel frames to enable application of load through stiffeners located at both ends of the beam (Figure 3). The frames were loaded quasi-statically in a cyclic fashion and load increase was controlled by two methods - force per cyclic step up to frame yielding, and displacement per cyclic step after yielding according to [1]. Experimental values of ultimate load and initial stiffness (primary indicators of global structural behaviour) are presented in Figure 4.
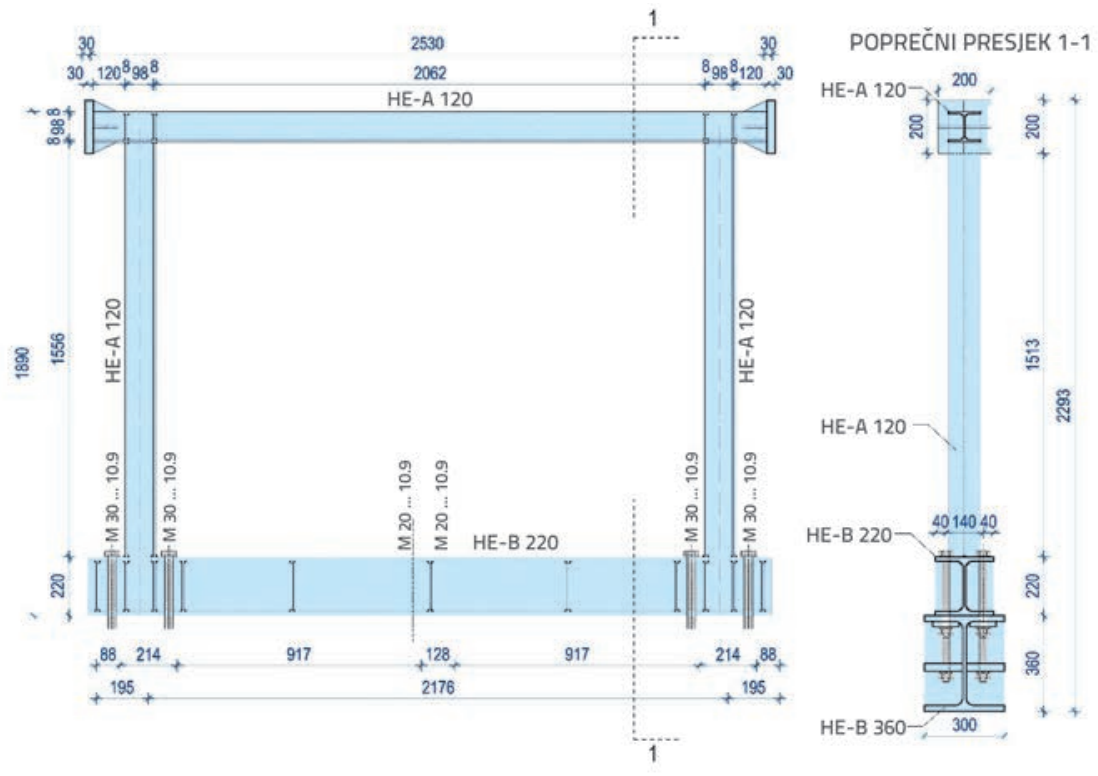

Figure 3. Dimensions of steel frames

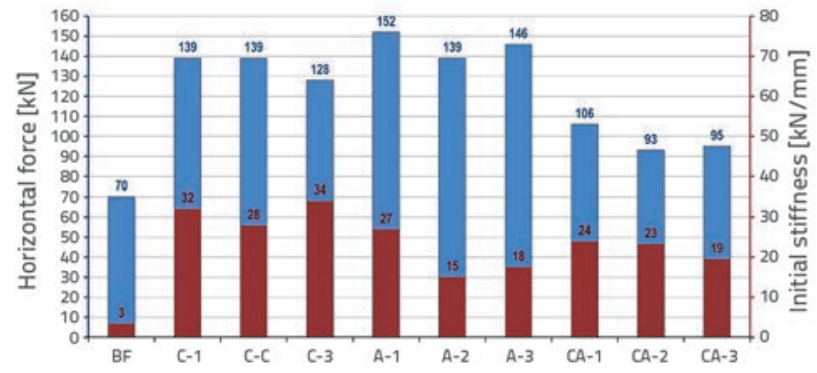

Figure 4. Ultimate load and initial stiffness of bare steel frame (BF), frames infilled with perforated clay blocks (C-I), AAC blocks $(A-I)$ and combined infill (CA-I)

In general terms, structural behaviour of individual series of specimens differed considerably from each other. Experimental results for $\mathrm{C}-i$ specimens show largest stiffness along with very high strength and almost smooth shape of the hysteretic curves. When the compression strength of infill was exceeded, diagonal cracking occurred with noticeable shattering and spalling of the outer layer of perforated clay blocks. This was a characteristic failure mode of the test series with the "strong" infill. Significantly different type of behaviour was observed in the case of A-i specimens. This kind of infill consisted of weak units bonded with strong glue and so it behaved atypically to masonry - the AAC block infill stayed in place and was capable of assuming load well into inelastic range (up to the drifts of $1.7 \%$ ).

Although the cracks were evenly distributed across the infill surface, the wholeness of the frame-infill interactive system was preserved for quite a long time, which is due to almost ideal bilinear elastoplastic behaviour of the AAC infill. Consequently, compared to C- $i$ specimens, a greater ultimate load along with smaller stiffness was achieved, and inelastic deformations occurred at the base of the steel column. Furthermore, behaviour of the third series with composite infill proved to be specific and differed considerably from previous two series.

The hysteresis envelope curves (primary curves) obtained for CA- $i$ specimens are shown in Figure 5 (other hysteresis curves can be found in [1]). The specimen CA-1 exhibited behaviour that was very close to the desired behaviour explained earlier on in the paper. Attempts were made to achieve two different phases of structural behaviour - the first phase characterized by monolithic action of the steel frame and combined infill, and the second phase with gradual cracking of the weakened interface 

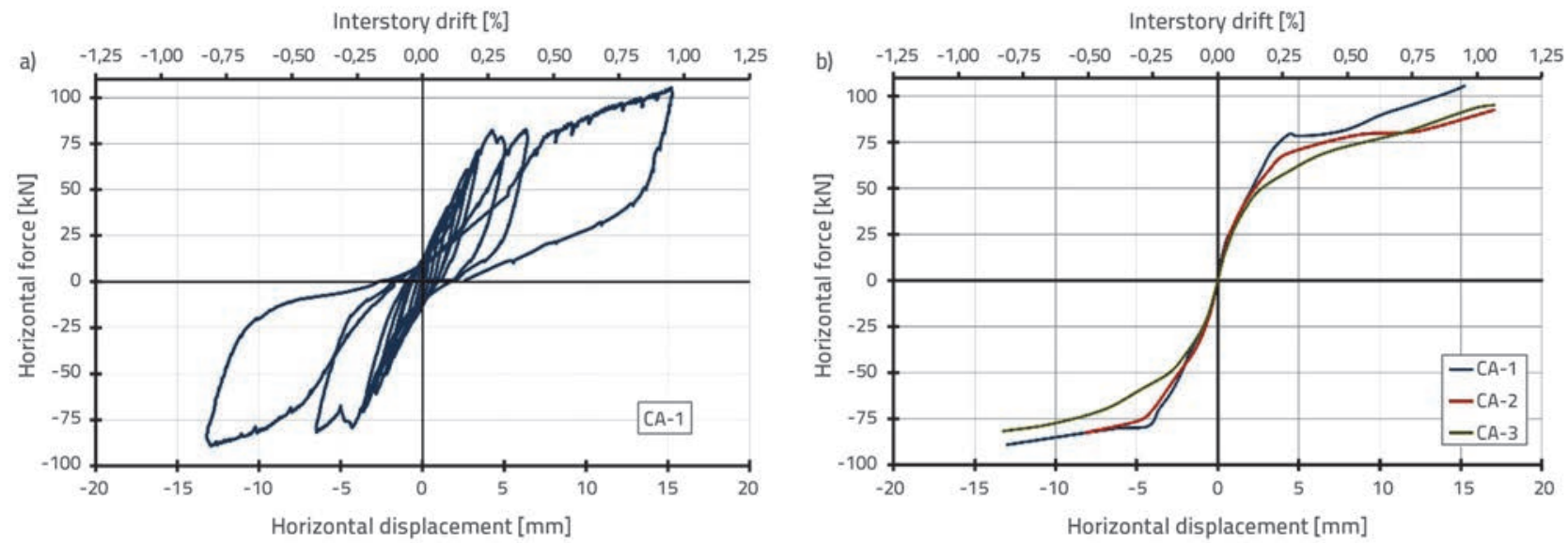

Figure 5. a) Hysteresis loops of CA-1 specimen; b) Hysteresis envelope (primary) curves of CA-i specimens

area and "clear" frame flexural behaviour afterwards. It was observed that the initial secant stiffness of specimen CA- 1 was comparable to the secant stiffness values of specimens $C-i$, which were generally slightly higher compared to A-i specimens, with the exception of specimen $A-1$ that showed atypical behaviour within the A-i series (Figure 4).

Further increase of load caused separation between the frame and infill, and so the central part of masonry infill remained practically undamaged, as can be seen in Figure 6. With regard to the cracked interface area between the frame and infill, proper attention should be paid to the out-of-plane restraint of the central infill panel part after "separation" from the frame (although separation will probably not progress rapidly along the whole frame-to-infill contact length). Falling out-of-plane could be prevented by suitable construction provisions - for instance by several vertical steel cords uniformly arranged along the frame length (on both panel sides), and elastically attached to the frame beam flanges, Figure 7. The infill panel could be plastered later, and so this intervention should not significantly affect the construction process.

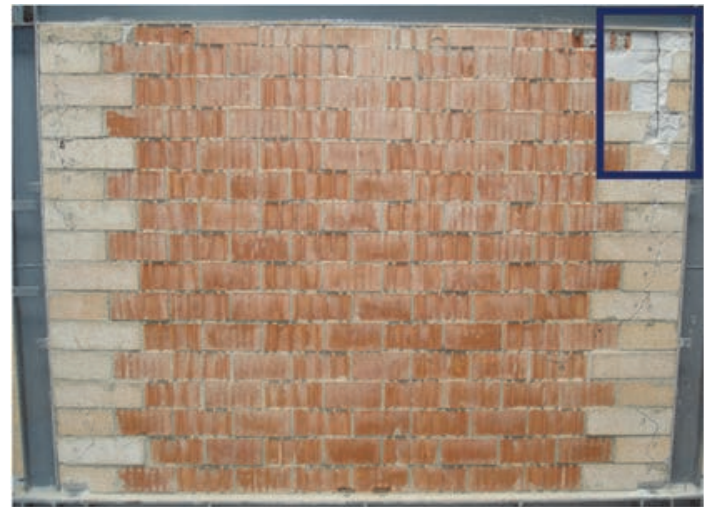

Figure 6. Photographs of specimen CA-1 after failure

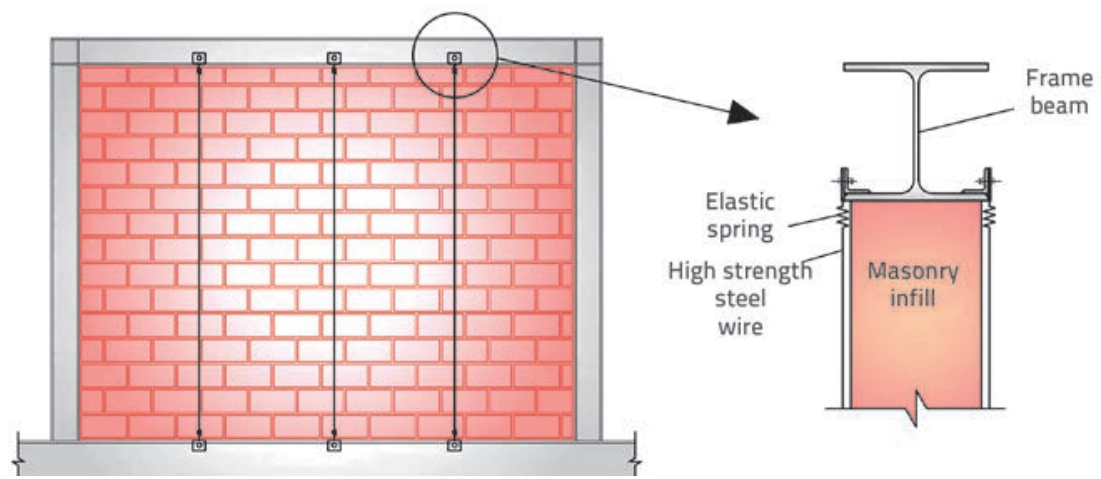

Figure 7. Example of preventing of out-of-plane failure

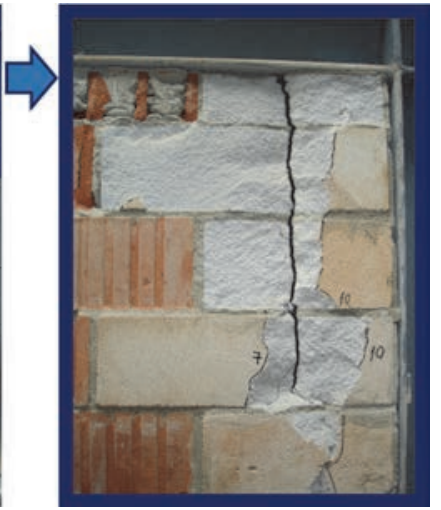

Keeping majority of the masonry infill undamaged, and thus enabling reparation of the contact area between the frame and infill, may sometimes bring significant savings during restoration of a building.

\section{Analytical modelling}

Experimentally measured data were used for calibration of relevant analytical models, which included both macro-models (single-strut and three-strut model, and infill-panel macro-model) and detailed 2D micromodels. The models with equivalent diagonals (single, multiple, and infill-panel) were very efficient for predicting global structural behaviour, Figure 8. The infill-panel macroelement model was acceptably reliable for all infill types. Micromodels were the most accurate models, with good prediction of the global and local behaviour indicators, Figure 9. Calibration process details can be found in [6]. 


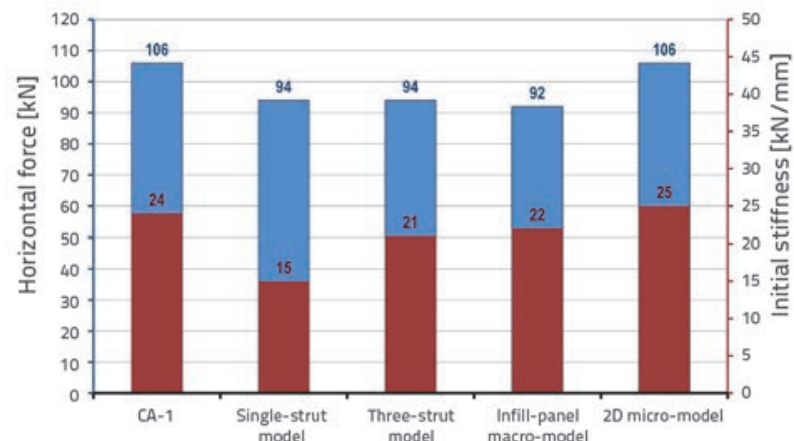

Figure 8. Comparisons of analytical and experimental results for CA-1 specimen

Calibration of the combined CA- $i$ specimens proved to be more difficult compared to the other two series because of its typical two-phase behaviour (i.e. "monolithic" and "separated"). Analytical models in which structural behaviour of infill is described as a whole were very effective - macro-models. Hence, in the case of the combined infill, a three-linear model (representing: initial stiffness, phase of cracking/separating, and residual strength) was used, while macro-models with the envelope curve consisting of four linear segments were more suitable for the $\mathrm{C}-i$ and $\mathrm{A}-i$ series (representing: initial stiffness, phase of cracking and reaching of peak strength, stiffness decrease after peak strength and residual strength). However, it should be noted that behaviour of the specimens infilled with AAC units can also be effectively modelled by bi-linear model, since their behaviour is atypical for masonry.

A highly efficient way to simplify and accelerate the infill modelling process is to use a predetermined finite element available in some FEM packages. One example is the inelastic infill panel element ("infill") implemented in Seismostruct software, [7]. The behaviour of that element is based on research carried out by Crisafulli and Carr [8] and Crisafulli [9], and the software is capable of describing most common modes of failure - the diagonal compression mode and the sliding shear mode.

However, in the case of micro-modelling, the actual situation can accurately be simulated, as shown in Figure 9. Software package ATENA 2D FEM has been used for that purpose, [10, 11].

In these models, two types of interface elements were created - the first type for modelling mortar joints in the masonry panel, and the second type for defining the contact line (interface) between the frame and infill. The weakened AAC blocks layer next to the steel frame was modelled with its clear depth, i.e. the real depth of the infill wall was reduced for the diameter of the drilled holes, as marked by dotted line in Figure 9.a.

Primary curves obtained using macro and micro models are shown in Figure 10.a and Figure 10.b, respectively, together with the group of averaged experimental primary curves. It can be seen that the model accuracy is at the satisfactory level.
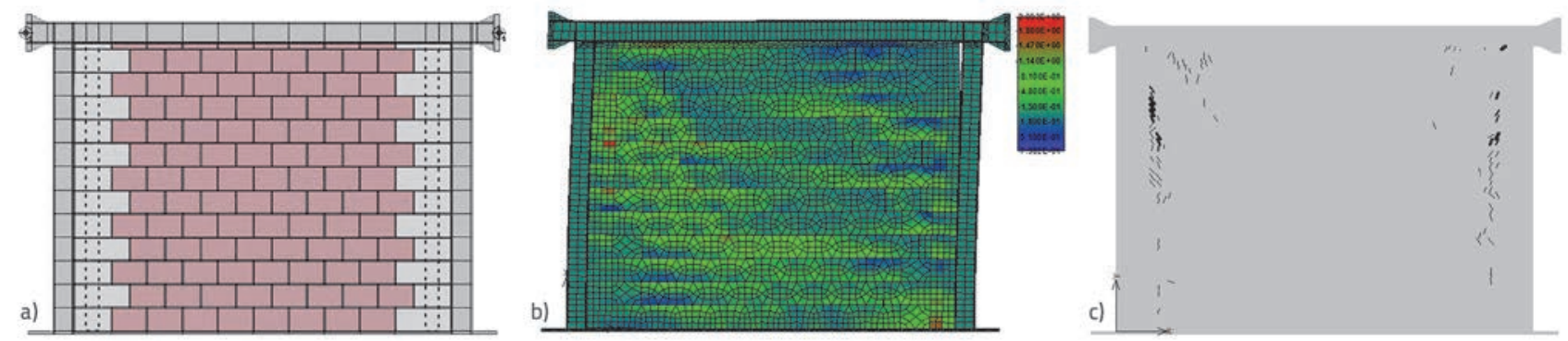

Figure 9. a) Micromodel of CA-i specimens; b) normal stress distribution at $0.5 \% \mathrm{drift}$; c) Crack pattern of CA-1 specimen at $1.0 \%$ drift

Interstory drift [\%]

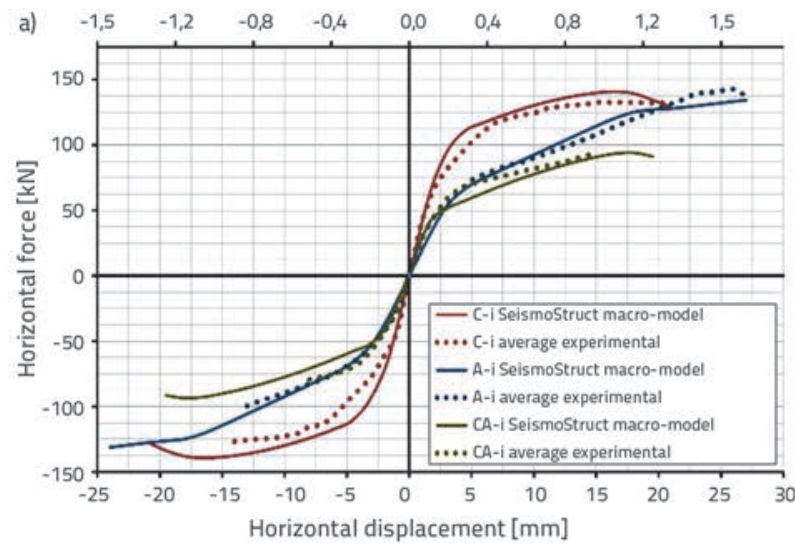

Interstory drift [\%]

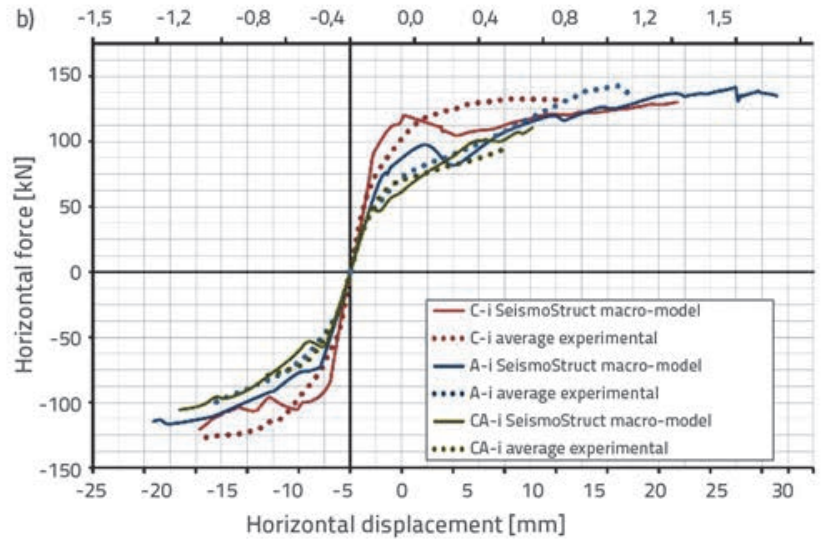

Figure 10. Primary curves obtained by: a) predetermined macro model (Seismostruct); b) micro-models (Atena 2D) 


\section{Numerical example}

Possibility of practical application of the composite infill is presented by the following numerical example. The building in question is a simple office building with rectangular floor plan measuring $14.00 \mathrm{~m} \times 12.00 \mathrm{~m}$, and is located in Osijek, Croatia. Structurally, it is made of a regular framework of steel frames infilled with three types of masonry infill considered in this paper (however, just one type of infill is simultaneously present in the building so that three different numerical models were created). The framework is formed of three parallel main plane frames spaced at $6 \mathrm{~m}$ intervals and connected by secondary beams, Figure 11. The main frames form two symmetrical $7 \mathrm{~m}$ bays and four floors. The height of the ground floor is $5 \mathrm{~m}$, while other floors are $4 \mathrm{~m}$ in height (with a total height of $17 \mathrm{~m}$ ). It is assumed that the floor system provides a "rigid" diaphragm. For the sake of simplicity, numerical analyses were performed for the plane frame on the axis B, Figure 11. The frame members were made of hot-rolled HEA profiles using steel grade S235 according to EN 10025. The imposed load was calculated with reference to category $\mathrm{B}$ [12] while roof category was $\mathrm{H}$. Climatic loads were determined according to relevant parts of Croatian National Annex to EN 1991. The seismic demand was computed according to EN 1998 [2] response spectrum (Type 1, soil type C, $a_{\mathrm{g}}=2.0 \mathrm{~m} / \mathrm{s}^{2}$ ). The beam-to-column joints were assumed to be rigid. Member sizes obtained by seismic and non-seismic load combinations according to EN 1990 [13] are given in Table 2.

The assessment of seismic vulnerability of the masonry infilled frame of concern was conducted by the displacement controlled pushover analysis performed using Seismostruct [7]. The elastic-ideally plastic material model with hardening [14] (post yield stiffness: $630 \mathrm{~N} / \mathrm{mm}^{2}$ ) with the yield strength of $f_{y}=235$ $\mathrm{N} / \mathrm{mm}^{2}$, and the modulus of elasticity amounting to $\mathrm{E}=210000$ $\mathrm{N} / \mathrm{mm}^{2}$, was used for modelling the steel frame. Material characteristics of various types of masonry infill previously obtained by calibration process were adopted in calculations, with the exception of infill thickness, which amounted to 19 $\mathrm{cm}$. Consequently, the correction of cross sectional area of the equivalent diagonal $A_{2}$ was also necessary in case of the combined (CA) infill. Characteristics of individual types of infill used in numerical calculations are given in Table 3, where: $E_{m}$ masonry elastic modulus, $f_{m}$ - masonry compressive strength,

Table 2. Member sizes of steel plane frame on axis B

\begin{tabular}{|c|c|c|c|c|c|c|}
\hline \multirow{2}{*}{$\begin{array}{l}\text { Load combinations } \\
\text { Floor }\end{array}$} & \multicolumn{3}{|c|}{ Non-seismic load combinations } & \multicolumn{3}{|c|}{ Seismic load combinations } \\
\hline & S3 & S4 & G2 & S3 & S4 & G2 \\
\hline Ground floor & HEA 280 & HEA 320 & HEA 300 & HEA 400 & HEA 400 & HEA 300 \\
\hline 1. floor & HEA 260 & HEA 280 & HEA 300 & HEA 320 & HEA 360 & HEA 300 \\
\hline 2. floor & HEA 240 & HEA 240 & HEA 300 & HEA 300 & HEA 300 & HEA 300 \\
\hline 3. floor & HEA 180 & HEA 240 & HEA 260 & HEA 280 & HEA 280 & HEA 240 \\
\hline
\end{tabular}
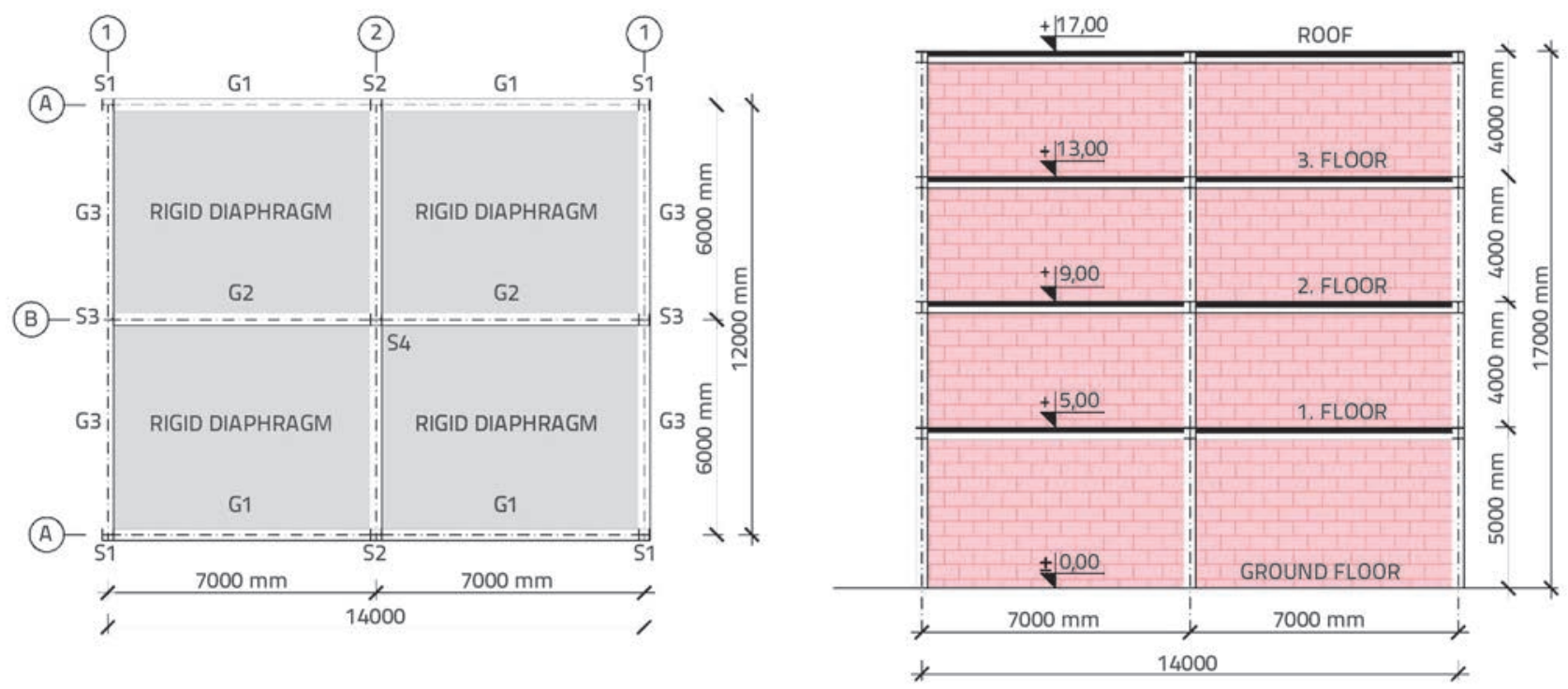

Figure 11. Plane view and elevation of the office building 
Table 3. Numerical characteristics of individual types of infill

\begin{tabular}{|c|c|c|c|c|c|c|c|}
\hline $\begin{array}{r}\text { Mechanical } \\
\text { characteristic }\end{array}$ & $\begin{array}{c}\boldsymbol{E}_{m} \\
{\left[\mathrm{~N} / \mathrm{mm}^{2}\right]}\end{array}$ & $\begin{array}{c}\boldsymbol{f}_{m} \\
{\left[\mathrm{~N} / \mathrm{mm}^{2}\right]}\end{array}$ & $\begin{array}{c}\boldsymbol{f}_{t} \\
{\left[\mathrm{~N} / \mathrm{mm}^{2}\right]}\end{array}$ & $\begin{array}{c}\varepsilon_{m} \\
{[-]}\end{array}$ & $\begin{array}{c}\varepsilon_{\text {ult }} \\
{[-]}\end{array}$ & $\begin{array}{c}\boldsymbol{c} \\
{\left[\mathrm{N} / \mathrm{mm}^{2}\right]}\end{array}$ & $\begin{array}{c}\boldsymbol{\mu} \\
{[-]}\end{array}$ \\
{$\left[\begin{array}{c}\tau_{\text {max }} \\
{\left[\mathrm{N} / \mathrm{mm}^{2}\right]}\end{array}\right.$} \\
\hline Clay blocks & 4600 & 1,42 & 0,195 & 0,0012 & 0,01 & 0,70 & 0,80 \\
\hline AAC blocks & 1200 & 1,01 & 0,215 & 0,002 & 0,03 & 0,30 & 0,35 \\
\hline Combined infill (CA) & 2900 & 0,55 & 0,215 & 0,002 & 0,004 & 0,30 & 0,35 \\
\hline
\end{tabular}

Table 4. Dynamic characteristics of analysed structures

\begin{tabular}{|l|c|c|c|c|}
\hline \multirow{2}{*}{ Lnalysed structures } & Load combination & $\begin{array}{c}\text { Non-seismic load combinations } \\
\text { ('- N') }\end{array}$ & \multicolumn{2}{c|}{$\begin{array}{c}\text { Seismic load combinations } \\
\left('-S^{\prime}\right)\end{array}$} \\
\cline { 2 - 5 } & $\begin{array}{c}\text { Natural period } T_{1} \\
{[\mathrm{~s}]}\end{array}$ & $\begin{array}{c}\text { Natural } \\
\text { frequency } f_{1} \\
{[\mathrm{~Hz}]}\end{array}$ & $\begin{array}{c}\text { Natural period } T_{1} \\
{[\mathrm{~s}]}\end{array}$ & $\begin{array}{c}\text { Natural } \\
\text { frequency } f_{1} \\
{[\mathrm{~Hz}]}\end{array}$ \\
\hline Bare steel frame (BF-N/BF-S) & 1,694 & 0,590 & 1,337 \\
\hline Steel frame with "strong" infill (clay blocks, C-N/C-S) & 0,263 & 3,802 & 0,251 & 3,748 \\
\hline Steel frame with "weak" infill (AAC blocks, A-N/A-S) & 0,444 & 2,252 & 0,428 & 2,336 \\
\hline Steel frame with "combined" infill (CA-N/CA-S) & 0,312 & 3,205 & 0,300 & 3,333 \\
\hline
\end{tabular}

$f_{t}$ - masonry tensile strength, $\varepsilon_{m}$ - strain at maximum stress, $\varepsilon_{u l t}$ ultimate strain, $c$ - shear bond strength, $\mu$ - friction coefficient, $\tau_{\max }$ - maximum shear strength.

The influence of infill on the steel frame behaviour can clearly be seen in Table 4, which shows dynamic characteristics of the analysed structures.

The results of numerical analysis in form of the base shearhorizontal displacement of the top of the building are presented in Figure 12. The response of a building considered as a system of frames offers a better insight into possible detrimental and beneficial effects of some systems. The effects observed at the single frame level are multiplied at the system level, and so the data gained from single frames (as seen in Figure 10) can be observed more clearly in such a manner. The numerical analysis of the same frames from the single frame analysis, grouped, shows significant positive effects in the post-earthquake context. There is a significant correspondence between the experimentally and numerically obtained results, but with more pronounced effects. It should be noted that in the case of numerical analysis the results after the 2,5\% drift have a theoretical significance only.

The development of plastic yield in structural members of the analysed systems at the $1.20 \%$ of interstorey drift is shown in figure 13. Taking into account the symmetry and simplicity of the structural system, as well as the use of a macro-infill Seismostruct element, it can be stated that the obtained results show only global behaviour of the analysed infilled frames, without some important effects that can significantly
Relative horizontal displacement at the top of the building [\%]

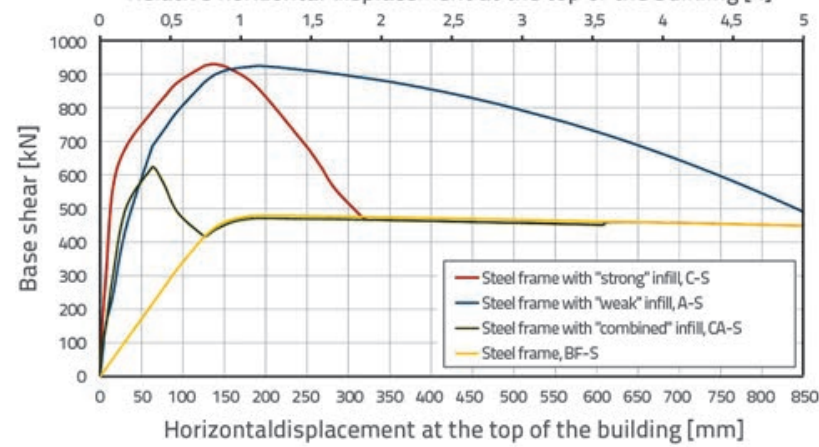

Figure 12. Base shear-horizontal displacement curve

affect structural behaviour (i.e. local effects, influence of connections, etc.). In the light of these facts, the observed sequence of plastic yield is quite similar within the analysed infilled frames, with a presence of a slight delay between individual systems. A higher level of similarity between the steel bare frame and the frame with combined infill was also noticed, as shown in Figure 13.

Furthermore, global structural characteristics, ultimate load and initial stiffness of the systems analysed in this numerical example are compared in Figure 14. It can be seen that the general trend is the same as in Figure 4 for experimentally obtained values of ultimate load and initial stiffness, and so the benefit of the combined infill can roughly be summarized as an increase in initial stiffness of the system and, at the 

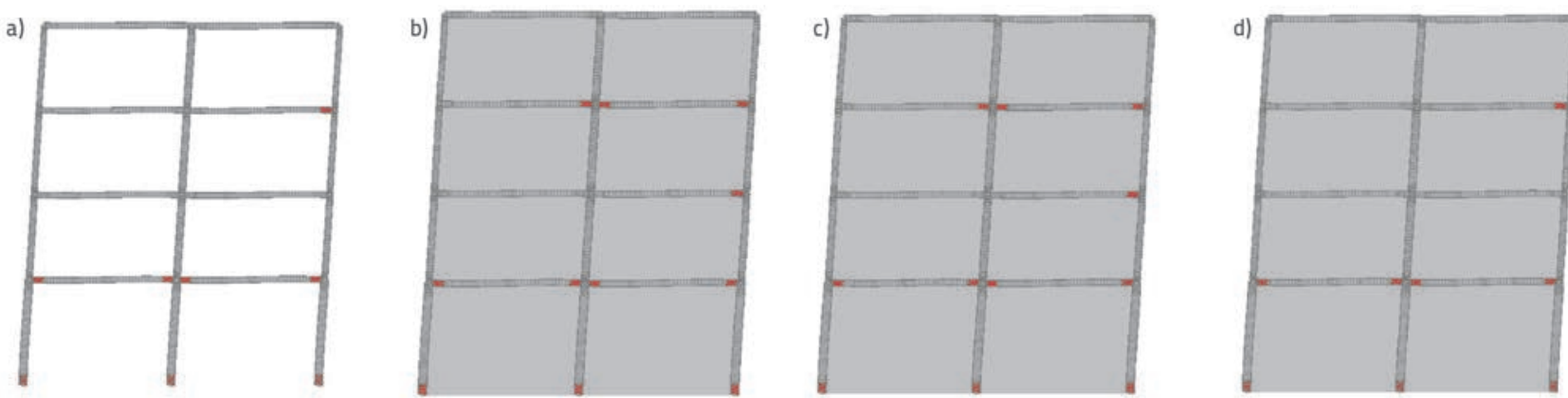

Figure 13. Development of plastic yield at $1.20 \%$ drift: a) bare steel frame; b) C-S system; c) A-S system; d) CA-S system

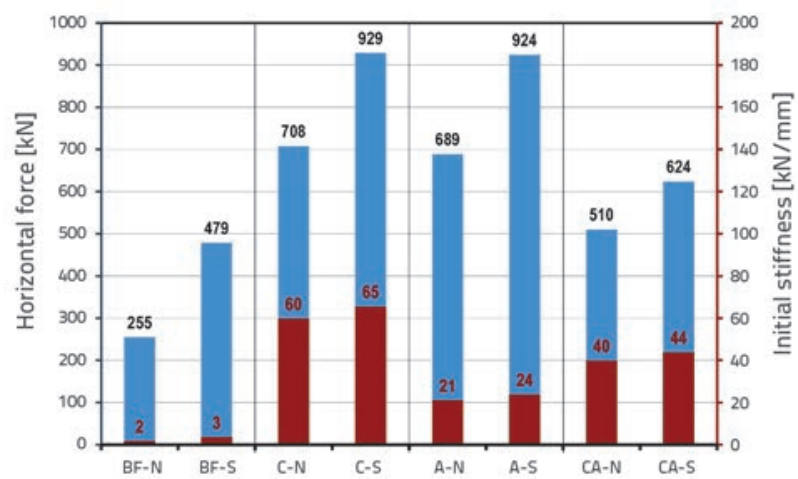

Figure 14. Ultimate load and initial stiffness values of analysed systems

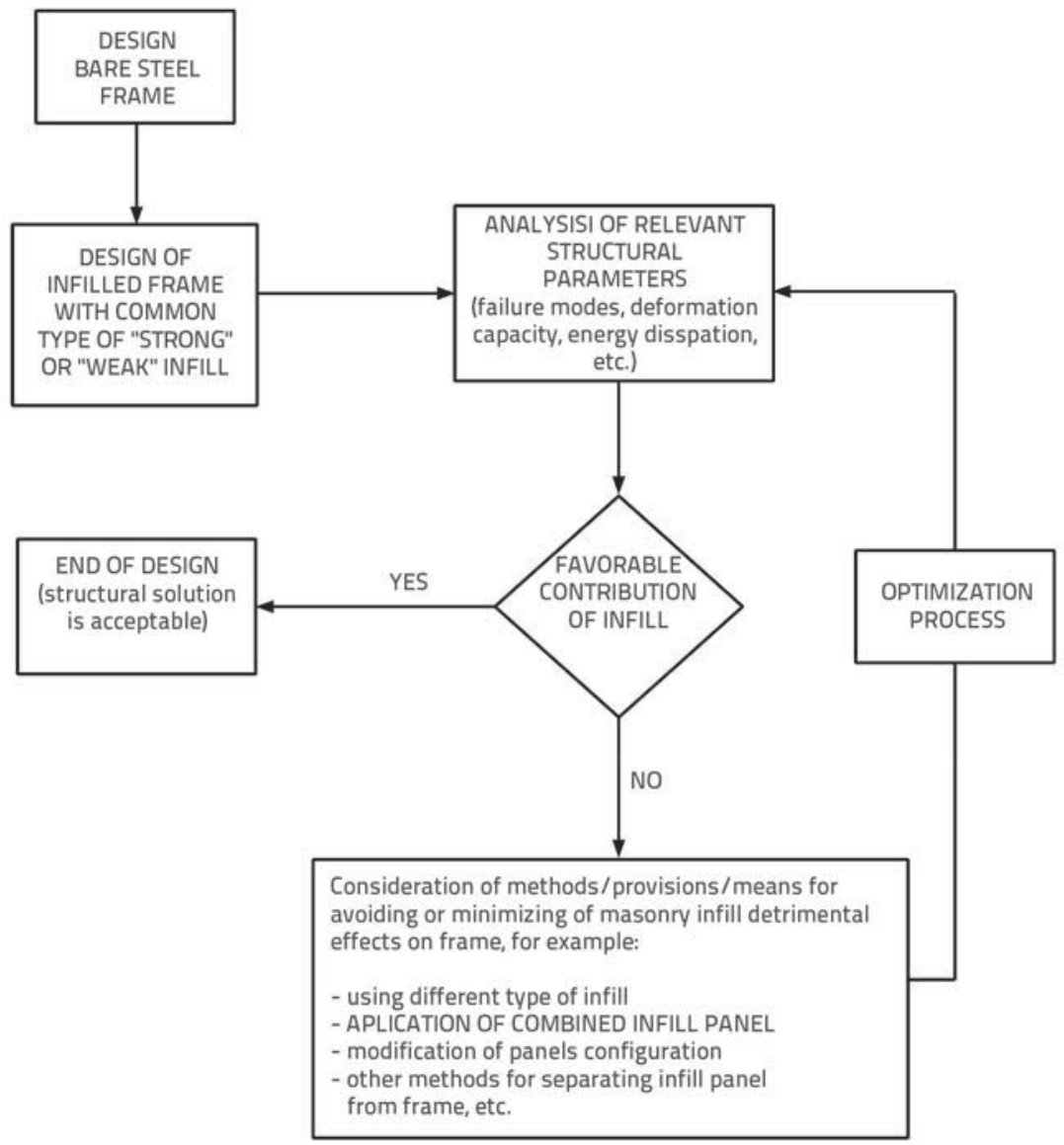

Figure 15. Iterative procedure for application of composite masonry infill same time, preservation of a "clear" flexural behaviour of the bare steel frame.

Finally, a practical recommendation for using the combined infill is schematically shown in Figure 15. Naturally, the use of common types of masonry infill will be the first solution in the majority of practical cases. However, alternative solutions have to be considered if the results of structural design indicate that the previously mentioned detrimental effects of the selected infill are likely to occur. Therefore, it is of great importance to first undertake the study of the influence of infill on the bare steel frame behaviour. If the study points to possible unfavourable effects of infill, then various methods and provisions for avoiding or minimizing these effects will be necessary. One of these could be the use of composite infill as explained in this paper.

\section{Conclusion}

Due to its favourable characteristics (availability, durability, good thermal and acoustical properties, as well as fire resistance, easy maintenance etc.) masonry is often used as frame infill. However, despite many research reports and published papers, structural behaviour of a new structure created by adding a masonry panel to a steel or concrete frame is hard to define in a straightforward manner. It cannot be achieved by mere addition of particular contributions of constituent parts of the new structure because of the highly non-linear behaviour resulting from ever-changing interactions between the masonry panel and the surrounding frame. Moreover, a common consent has not even been reached about the name of the new structural system, and so the system is designated in literature as "composite", "hybrid", "dual", "combined", "interactive" etc.

The main goal of this paper was to investigate the possibility of achieving 
controlled behaviour of the masonry infilled steel frames by using simple construction provisions. The emphasis is on the word "simple" because of our wish to retain each of the above mentioned favourable characteristics of masonry on the one hand, and to increase practical significance of the method on the other. In our case, by simple construction provisions we considered a specific combination of common types of masonry infill.

The experimental testing of infilled steel frames encompassed three series of specimens differentiated by the type of masonry infill, namely perforated clay units, lightweight AAC units, and their particular combination. The obtained results can be summarized as follows:

1. the experimentally observed structural behaviour of each tested series was very different:

- the steel frames infilled with perforated clay units exhibited the largest stiffness and an almost smooth shape of hysteretic curves, while failure was caused by exceedance of compression strength of the infill, followed by diagonal cracking and noticeable shattering and spalling of the perforated outer layer of clay blocks (the observed behaviour was completely "masonry-like");

- hysteretic curves of steel frames infilled with AAC units were rising and were more elongated, and so these specimens exhibited the greatest ultimate load along with significant inelastic deformation of the steel frames (up to the drifts of $1.7 \%$ ); the cracks were evenly distributed across the whole infill and, generally, structural behaviour of this series can be described as "masonry-unlike";

- hysteresis loops of the specimens with combined infill had a specific "two-phase" shape wherein the specimen with the smallest hole $(\mathrm{C}-1)$ was closest to the desired structural behaviour; in the first phase, the infilled frame exhibited monolithic behaviour and had higher stiffness and load capacity compared to the bare steel frame, while the second phase started with gradual cracking of the weakened masonry area adjacent to the steel frame; separation between the infill and frame followed with decrease in stiffness was obvious in the end, which in turn enabled flexural action of steel for higher load levels; weakening of the other two specimens from this series was too big, and led to premature separation between the infill and frame, which was unintentional; generally, the observed behaviour was a combination of two systems: an infilled frame and a bare steel frame;

2. common analytical models of tested specimens were created and calibrated on the basis of the previously conducted experimental tests; when the use of analytical macro-models is of concern, behaviour of infill panels made of perforated clay units can be effectively modelled by an appropriate multi-linear curve defined by four linear segments (corresponding to: initial stiffness, phase of cracking and reaching peak strength, stiffness decrease after peak strength, and residual strength); bi-linear envelope curve was also very efficient in the case of the panels made of AAC units, while structural behaviour of the specimens infilled with combined infill can be adequately modelled by a three-linear model (representing: initial stiffness, cracking/ separating phase, and residual strength); the predetermined macro-model given in Seismostruct software was very useful for modelling all tested series, not only because of the relatively easy modelling process but also due to fast calculation capabilities.

3. the application of calibrated analytical models of all three types of infilled steel frames is illustrated by numerical example of structural design of a simple office building; the results obtained were qualitatively in accordance with the conducted experimental tests, and they further clarified structural behaviour of a specific type of tested infill; a practical recommendation for using the composite infill is given; this solution is especially suitable in cases where an application of "common" types of masonry infill proves to be inadequate due to their detrimental effects on structural behaviour of bare steel frames; a special attention should be paid to the falling out-of-plane of composite panels, which must be prevented by suitable construction provisions (an example of these provisions is given in the paper).

\section{Acknowledgments}

The research presented in this paper is a part of the research project "Seismic design of infilled frames", No. 149-14929661536 , conducted with the assistance of the Ministry of Science, Education and Sports of the Republic of Croatia, whose support is gratefully acknowledged.

\section{REFERENCES}

[1] Markulak, D., Radić, I., Sigmund, V.: Cyclic testing of single bay steel frames with various types of masonry infill, Engineering structures, 51 (2013), pp. 267-277, https://dx.doi.org/10.1016/j. engstruct.2013.01.026
[2] European Committee for Standardization: EN 1998-1, Eurocode 8: Design of structures for earthquake resistance - Part 1: General rules, seismic actions and rules for buildings. Brussels, Belgium, 2005. 
[3] Kauffman, A., Memari, A.M.: Performance Evaluation of Different Masonry Infill Walls with Structural Fuse Elements Based on InPlane Cyclic Load Testing, Buildings, 4 (2014) 4, pp. 605-634, https://doi.org/10.3390/buildings4040605

[4] Preti, M., Bettini, N., Plizzari, G.: Infill walls with sliding joints to limit infill-frame seismic interaction: Large-scale experimental test, Journal of Earthquake Engineering, 16 (2012) 1, pp. 125141, https://doi.org/10.1080/13632469.2011.579815

[5] Mohammadi, M., Akrami, V.: An engineered infilled frame: Behavior and calibration, Journal of Constructional Steel Research, 66 (2010) 6, pp. 842-849, https://doi.org/10.1016/j.jcsr.2010.01.008

[6] Radić, I., Markulak, D., Sigmund, V.: Analytical modelling of masonry-infilled steel frames. Tehnički vjesnik, 23 (2016) 1, pp. 115-127, https://doi.org/10.17559/TV-20150528133754

[7] SesimoStruct - A Computer Program for the Static and Dynamic Analysis of Framed Structures, http://www.seismosoft.com/ Public/EditorUpload/Documents/SeismoStruct_User_Manual_ en.pdf,26.4.2016.

[8] Crisafulli, F.J., Carr, A.J.: Proposed macro-model for the analysis of infilled frame structures, Bulletin of the New Zealand Society for Earthquake Engineering, 40 (2007) 2, pp. 69-77.
[9] Crisafulli, F..:: Seismic behaviour of reinforced concrete structures with masonry infills, University of Canterbury, PhD thesis, 1997.

[10] Červenka, V., Jendele, L., Červenka, J.: ATENA Program Documentation - Part 1 - Theory, www.cervenka.cz/assets/files/ atena-pdf/ATENA_Theory.pdf, 26.4.2016.

[11] Červenka, V., Červenka, J.: ATENA Program Documentation - Part 2-1 - User's Manual for ATENA 2D, http://www.cervenka.cz/ products/atena/documentation/pdf-users-manual-for-atena2d, 26.4.2016.

[12] European Committee for Standardization: EN 1991-1-1, Eurocode 1: Actions on structures - Part 1-1: General actions - Densities, self-weight, imposed loads for buildings, 2002.

[13] European Committee for Standardization: EN 1990, Eurocode 0 Basis of structural design, 2002.

[14] European Committee for Standardization: EN 1993-1-5, Eurocode 3: Design of steel structures - Part 1-5: Plated structural elements, CEN, Brussels, Belgium, 2006. 